\section{Britain's science saga}

British politicians are beginning to take an interest in the state of science. Not before time.

THIS week's debate in the House of Commons on the condition of the research councils whose chief function is the support of academic research is a landmark of a kind. It is a long time since such a question was raised in such a setting. And while there is no reason to expect that the new government will admit the errors of its predecessor's ways, there is at least a chance that it may be forced in future to be less cavalier than has been the custom.

But this week's debate (which will already have taken place by the time this issue is widely read) is narrow in scope, and chiefly concerned with the most recent cutting of the cake that is annually divided between the five research councils. It will be right and proper if the government has been given a drubbing over its decision to break with a precedent set by the then Sir Keith (now Lord) Joseph, when Secretary of State for Education and Science in the early 1980 s, to publish the independent advice on which the cake-cutting was based. Joseph, hardly renowned for his attachment to open government, had soundly concluded that no harm would come of making the advice public even when he chose to override it. Of what is the new government afraid?

But the chances are that this week's debate will also have revealed the dangers inherent in arguments such as this over the budgetary problems. In particular, they create the impression that the problems of British science are money problems. Money matters, and more money would be beneficial in the present circumstances in which good projects are being held up or cancelled through budgetary accidents, but the serious troubles with British science are more deep-seated. The serious reason for alarm is that the research community is beginning to reap the painful reward for a decade's preoccupation by others with the supposed short-term benefits of research.

Not that British science is all dust and ashes. As the world knows, many laboratories retain an international standing, while many academic departments (in polytechnics as well as universities) have found it possible successfully to make their way in the half-commercial world of which the previous government was enamoured. None of that is all that difficult, or in itself offensive. The more serious threat to the research community lies in the hints provided by university entrance figures of the alienation of young people from technical careers and in the certain if anecdotal evidence that more senior people are heading steadily overseas. For Britain as a whole, the risk is that the impending shortage of trained researchers, required as much by industry as by academic institutions, will go unremarked until recovery is virtually impossible.

That is why, on some occasion, there should be a debate in the House of Commons (or somewhere) with much broader terms of reference. The endless argument about money is not unimportant, but there is a more interesting argument to be had about the means that might be taken, within the debris of the past decade's neglect, to begin reconstructing British science. That will ultimately require a reconstruction of some part of the educational system, some means of giving academic institutions a flexibility they lack at present and a means of persuading young people that science is as much fun as earlier generations have found it. As the chief potential beneficiaries, researchers themselves should be prepared to lend a hand in this cause.

\section{Hobson's choice?}

Germany's new education minister, an easterner, will have a struggle to prove himself.

SINCE the reunification of Germany, it has been clear that places would have to be found in Chancellor Helmut Kohl's cabinet for a sprinkling of easterners, but there is some dismay in academic circles that the education ministry has been one of the first portfolios dealt with in this way. There are several causes for anxiety. First, the education ministry is relatively new, having been carved out of the research ministry as recently as 1972 . But in German education, the states or Länder are constitutionally dominant, so that a minister needs guile and political skill if he is to exert influence. Yet the new minister, mathematician Rainer Ortleb from the University of Rostock, has virtually no experience of western-style government, and will certainly begin as a pale shadow of his predecessor Jürgen Mölleman who has been promoted to the economics ministry.

It is to Ortleb's credit that he has managed to survive in high office for half a year without falling prey to the investigations of journalists and prosecutors seeking to demonstrate links between eastern politicians and the former East German secret police. Ortleb was a member of the Liberal Democratic Party, which dutifully delivered votes to the old Communist party until 1989. On reunification and the merger of the liberal democrats with West Germany's free democrats (who are the junior partners in the Kohl coalition), Gotleb floated to the top, becoming one of the three easterners in the eighteenstrong federal cabinet.

Gotleb's more immediate difficulty is Mölleman's legacy. Although something of a gadfly, Mölleman knew how to use his post in education to suggest that his ideas were the next best thing to reality. He struck many adventurous blows for the condition of young researchers and women in German universities, in the process angering the Länder, irritating the federal government, but winning the applause of the research community. Mölleman also argued against the search for student numbers at universities in exchange for quality. Gotleb deserves a chance to show his mettle, but it is likely to be some time before he emerges from Mölleman's shadow. 